\title{
Response to Damiani and colleagues
}

\author{
J-L Diehl1 ${ }^{1,2,3^{*}}$ (D) N. Peron ${ }^{3}$, A. Philippe ${ }^{1,2,4}$ and D. M. Smadja ${ }^{1,2,4}$
}

\section{To the Editor,}

We have read with great interest the comment of Damiani on our article, retaining the hypothesis of a possible major role of microvascular derangement in the physiopathology of COVID-19 ARDS. Such a hypothesis, supported by a number of arguments such as the rich expression of the SARS-CoV-2 ACE2 receptors in lung endothelial cells and dysregulation of the renin-angiotensin system, is now widely mentioned by others, using different approaches such as EIT studies [1], high-energy CT studies [2] and histopathology studies [3].

Damiani et al. have put our results in perspective with their own published observations of an inverse relationship between sublingual perfused vessel density and D-dimers in mechanically ventilated patients with severe SARS-CoV-2 pneumonia. They also reported a tendency to a decrease in sublingual microcirculation in patients with increased driving pressures. Interestingly, we observed in our 22 patients an inverse relationship between circulating endothelial cells (CECs) and total respiratory system compliance $(r=-0.278, p=0.017)$, which could suggest a parallel between microvascular and alveolar insults, perhaps in relation with the hemodynamic consequences of a more severe alteration in respiratory mechanics. To explore if COVID-19 ARDS patients could exhibit a lung-specific microvascular response to high PEEP levels, as compared to non-COVID-19 ARDS patients, seems to be an important field of investigation.

One important point is that the very vast majority of studies in COVID-19 ARDS patients used, by convenience, ventilatory ratio (VR) as a marker of impaired ventilatory efficacy, as mentioned in Damiani's comment, rather than dead space measurements. However, it must

\footnotetext{
*Correspondence: jean-luc.diehl@aphp.fr

${ }^{3}$ Medical Intensive Care Unit, AH-HP, Georges Pompidou European

Hospital, 20 rue Leblanc, 75015 Paris, France

Full list of author information is available at the end of the article
}

be pointed out that VR was not originally designed to be used as a surrogate of dead space [4]. Accordingly, although highly significant, we found only a moderate level of correlation between VR and physiological dead space $\left(V_{D} / V_{T}\right)$ [5]. The level was even lower than the values found in the non-COVID-19 ARDS literature.

We appreciate the opportunity to discuss some very important technical points in relation to capnography methods and the derived indexes. Damiani et al. state that our $V_{D} / V_{T}$ measurements could be inaccurate, due to transport delay of gas together with variable sampling flow rate. However, this point (and others also considered as disadvantages of the side stream method) is counterbalanced by specific disadvantages of the mainstream method which could also influence the precision of the results. Altogether, it is generally considered that there are advantages and disadvantages of both, the choice between them being of personal preference or from availability (as in our cohort of COVID-19 ARDS) rather than from strong recommendation [6]. Nevertheless, we agree that knowledge of physiologic and technologic basis of capnography is absolutely mandatory, both for research purposes and also for monitoring of ICU patients [7].

Finally, it will be important to further precisely investigate the relationship between dead space measurements, with a special focus on indicators of alveolar dead space, and markers of endothelial dysfunction, such as bio-markers (such as CECs and D-dimers) and innovative methods such as the video-microscopy methods used by Damiani and colleagues. Ideally, such prospective studies should include COVID-19 ARDS patients and non-COVID-19 ARDS patients as a control group. They should include measurements performed at different PEEP levels. They should also include measurements performed during the full course of invasive mechanical ventilation.
SpringerOpen

(c) The Author(s) 2020. This article is licensed under a Creative Commons Attribution 4.0 International License, which permits use, sharing, adaptation, distribution and reproduction in any medium or format, as long as you give appropriate credit to the original author(s) and the source, provide a link to the Creative Commons licence, and indicate if changes were made. The images or other third party material in this article are included in the article's Creative Commons licence, unless indicated otherwise in a credit line to the material. If material is not included in the article's Creative Commons licence and your intended use is not permitted by statutory regulation or exceeds the permitted use, you will need to obtain permission directly from the copyright holder. To view a copy of this licence, visit http://creativeco mmons.org/licenses/by/4.0/. 


\section{Acknowledgements}

We would like to acknowledge all nurses, technicians and physicians involved in the George Pompidou European Hospital for help in taking care of patients and including them in the study.

\section{Authors' contributions}

Substantial contributions to the conception or design of the work: JLD, DS. Drafting the work or revising it critically for important intellectual content: all authors. Agreement to be accountable for all aspects of the work in ensuring that questions related to the accuracy or integrity of any part of the work are appropriately investigated and resolved: all authors. All authors read and approved the final manuscript.

\section{Funding}

No specific funding.

\section{Availability of data and materials}

The datasets used and/or analyzed during the current study are available from the corresponding author on reasonable request.

\section{Ethics approval and consent to participate}

Patients mentioned in the response were included in the French-COVID national cohort after informed consent of proxies or family members by phone, due to quarantine. Additionally, proxies or family members gave also an informed consent by phone for a formalized local process of collecting biological samples in relation to cardiovascular, metabolic or renal diseases (Comité de Protection des Personnes Ile-De-France II, IRB registration 00001072, approval: November 11, 2016)

\section{Consent for publication}

Not applicable.

\section{Competing interests}

All the authors have nothing to disclose.

\section{Author details}

1 Université de Paris, Innovative Therapies in Haemostasis, INSERM, 75006 Paris, France. ${ }^{2}$ Biosurgical Research Lab (Carpentier Foundation), 20 rue Leblanc, AH-HP, Georges Pompidou European Hospital, 75015 Paris, France. ${ }^{3}$ Medical Intensive Care Unit, AH-HP, Georges Pompidou European Hospital, 20 rue Leblanc, 75015 Paris, France. ${ }^{4}$ Hematology Department, AH-HP, Georges Pompidou European Hospital, 75015 Paris, France.

Received: 28 September 2020 Accepted: 6 October 2020

Published online: 14 October 2020

\section{References}

1. Mauri T, Spinelli E, Scotti E, Colussi G, Basile MC, Crotti S, et al. Potential for lung recruitment and Ventilation-Perfusion mismatch in patients with the acute respiratory distress syndrome from coronavirus disease 2019. Crit Care Med. 2020;48(8):1129-34.

2. Patel BV, Arachchillage DJ, Ridge CA, Bianchi P, Doyle JF, Garfield B, et al. Pulmonary angiopathy in severe COVID-19: physiologic, imaging, and hematologic observations. Am J Respir Crit Care Med. 2020;202(5):690-9.

3. Ackermann M, Verleden SE, Kuehnel M, Haverich A, Welte T, Laenger F, et al. Pulmonary vascular endothelialitis, thrombosis, and angiogenesis in Covid-19. N Engl J Med. 2020;383(2):120-8.

4. Sinha P, Fauvel NJ, Singh S, Soni N. Ventilatory ratio: a simple bedside measure of ventilation. Br J Anaesth. 2009;102(5):692-7.

5. Diehl J-L, Peron N, Chocron R, Debuc B, Guerot E, Hauw-Berlemont C, et al. Respiratory mechanics and gas exchanges in the early course of COVID-19 ARDS: a hypothesis-generating study. Ann Intensive Care. 2020;10(1):95. https://doi.org/10.1186/s13613-020-00716-1.

6. Hess D. Capnometry. In: Principles And Practice Of Intensive Care Monitoring. Tobin MJ edit. 1997:377-400.

7. Diehl J-L, Chamoun C, Mercat A, Richard JC, Guérot E. An unusual sidestream capnogram. Br J Anaesth. 2017;118(5):807-8.

\section{Publisher's Note}

Springer Nature remains neutral with regard to jurisdictional claims in published maps and institutional affiliations.

\section{Submit your manuscript to a SpringerOpen ${ }^{\circ}$ journal and benefit from:}

- Convenient online submission

- Rigorous peer review

- Open access: articles freely available online

- High visibility within the field

- Retaining the copyright to your article

Submit your next manuscript at $\boldsymbol{\nabla}$ springeropen.com 